\title{
Adorno's Modern Music Attitudes in "Introduction to the Sociology of Music"
}

\author{
MA Qun \\ Harbin normal university music college, Harbin, China \\ maqun9@13.com
}

Keywords: Adorno; modern music; spirit of the times.

\begin{abstract}
In the eleventh chapter of "Introduction to the Sociology of Music", Adorno put forward his own views on the development of modern music. He believes that modern music is the most sensitive nerve of society, which shows the turbulence of social structure ahead of other arts. Adorno commends the composer who still adhere to express the inner spirit in the society that economy dominates everything and critiques those musical works according to the traditional rule in order to obtain social affirmation. His critical thought paces with the times characteristics, and it is also of great significance for the development and direction of 21 century music in society.
\end{abstract}

\section{Introduction}

Western modernist music refers to all professional music after impressionistic music in the late 19th and early 20th century. In terms of historical style category, modern music refers to the works with special style in the 20th century, but it does not mean all works written in the 20th century. The generation of modern music is composed by two reasons, from the internal structure, it is due to the full development of the late Romantic musical language and style, and from the external structure, people affected by the two world wars, therefore, the development of science and technology played a catalytic role for the rise of modern music. Adorno said: maintaining the new music adapts social trends. The music that fully reflects the social content in modern music is called the "new music" by him. The substance of the new music is the resistance to social change. No matter in which era, the composer's creation can be often able to determine the trend of social thought, therefore, a good music must be a correct response for the today's society phenomenon. Adorno believes that good art must be associated with social content, and reject the temptation economy, and the new music is such a work of art.

\section{The development of modern music and the audience's aesthetic gap}

Modern music arose prior to the 1920s, due to the impact of the First World War, the dark political oppression gave composers creative inspiration, although the new music at this time is to be treated as a scandal, it is still being sought by a small number of people, for example, Schoenberg's twelve-tone music caused a sensation in the development of new music just beginning. Adorno thought most of the reason that these followers pursuit Schoenberg is the worship for composer and they can not fully understand the content of the music. To the 1940s, people are in the pain phase after the war, they are no longer interested in music, so tone again be applied in music. In politically sensitive era, it is very risky appearing against emotions in music, while the musicians can not openly show these emotions in music, some avant composers still put them invisible interspersed with music. At this time, there are some composers noticing the gap between music and listener, for example, composer Copland perceived the danger of working in a vacuum, while a number of new music listeners has grown around the radio and the phonograph. Whether we can use language as simple as possible to express what I want to express[1]. The composer's creation adapts to the audience to understand, and the types of music develop from "the performance of music" toward "practical music". 50, 60 years is the culmination of the development of modern music, due to the increased of aesthetic experience, this "collective experience gap" narrowed, making new music bring people more musical experience with the development of 
technology, and at that time, modern music really accepted by the public. For nearly six decades, in addition to composer continuing to explore experimental works, popular music aesthetic taste can not keep up the music social trends is the most important reason for the slow development of modern music. Modern music is obscure for the general public,and the audience can not understand what modern music perform. The development of modern music is not sensible expressive music, for composers pursuit inner spiritual music, and their work reflects a serious professional, this is a reaction to the social unrest, it is to adapt the content community.

Adorno said: "The latest music admits the remnants of chance events in universality, and this remnant is unified with rational society irrational spirit in nature"[2]. Composers found irrational war content in a rational society, as a phenomenon of the art, music expresses music that is different from the past through a special form of creation. Irrational spirit is the irrational of traditional music, and the rational same is the society same. This rational emotion-free music, in fact, also expresses some emotion and that is the resistance to this rational society. In the course of development, society itself added the "civilization", "harmony" and other elements, in fact, to the 20th century, social harmony elements is less and less, the machines instead of human production. Composer's mind has been changed by social forms, "rational" and "technology" occupiers of their creative nerve, and The only constant is the inspiration and musical revolutionary spirit that can not be suppressed in their brain. Modern music is famous for "rational" and "no emotion", composers create music based on the resentment that generated by social change through imitating modern society, I.e. Adorno said, "no longer have any human content with condemning the inhuman environment", which is undoubtedly the composer revolt against modern society. Changes in social productive forces, political unrest, genocide ...... in the face of terror social environment, making composer can no longer create music through mental and physical pleasure.

In terms of the structure of modern musical aesthetic, Adorno put the audience into "layman audience" and "special home audience". Although specialists audience can read the meaning of modern music, they are familiar with the music and ignore the music key emotional part that is concerned by the uninitiated audience. Modern music does not give the audience any emotional sustenance. The people familiar with the composer or understanding music support music because they are standing professional point of view, and the music appreciation values the internal structure of music, therefore, they can not hear the most intuitive content "insanity" in the music, and this kind of "insanity" appearance is a manifestation of the emotional expression of modern music social content. Although Adorno commended the modern music embodied the "spirit of the times", standing on the perspective of the audience, he believes either supporting or denying the new music is not wrong, integrated thinking aesthetic music is the "specific thinking performance". The more irrational content of modern music reflecting, the more rationality. The author believes whether it is "layman audience" or "special home audience", have learned the true intentions of the different aspects of modern music, "specialists audience" found a rational factor in composing techniques, and "layman audience" heard irrational factors the music expressed, so no matter on which hand, the state of society is to be true performance.I

\section{The opposition of Pioneer and non-Pioneer}

Adorno thought in the twentieth century, class position is not the most important criterion to judge a person whether is a outstanding composers. He criticized those composers who obey the needs of society and benefit from the society, thinking that "they have already decayed before the music come alive on impulse". These composers cater to the preferences of the audience or repeat the previous creative method which has no innovation in the development of music. Adorno called this music as "social entropy" (something meaningless and worthless in sociology). Adorno that modern music should "abandon the kind of appearance" and reflect the "true spirit of music". There are many excellent modern composers who don't born in a musical family, nor in the small strong group, but they know the thing that they are eager to show in his mind and the thing that is consistent with the spirit world[3]. Adorno praised the composer who expressed the true spirit of the content, and these people can tolerate the lack of substance and spirit of loneliness, which is a rare 
quality in this economic era. At the same time, he criticized the small group (music organization), because its independence and have a strong contrast with the community identity, in the early 20th century, this small group is regarded as "purity of protection" and its offspring was given great hope, thinking they are the heirs of the new music, however, these people absorb nutrients in the residue that has been critiqued and outdated. Such music is not in line with the laws of society, and music also have no soul.

The development of cultural industries prompted the birth of market economy oriented. In the 1930s, there was a new form of performance appearing with the needs of society. Such performances with movement and expression, it is more adapted to the needs of the audience, and its purpose is to serve the audience in order to meet the needs of the target audience to create. People were very willing to accept the occasion on behalf of the social trends, to watch this show had become a fashionable activity, it seems that it is not a bad thing that make composers service for them. For the creation of this show, managers and composers use the full range of talents to combine with music, performances and use. Meeting the needs of the audience, reducing quality of the music, so that in this show there is no spirit in the music at all. In music of this type in the show, "Utility" is also important compared with the new music "spirituality". In order to meet the needs of the audience, the composer adjusted integrated musical performances. Adorno believes that music creation, performance and acceptance should be split off, if these parts are combined, regardless of which part of the play is meaningless, for the performance just to meet the needs of the audience.

\section{Conclusion}

In the development of society, the music can reflect spirit of the times and in all aspects, In the 21st century today, the music market phenomenon is more and more obvious, but he real spirit of music has become increasingly distant from the public. The reason Adorno pays great importance to the mental function in modern music is that music spirit can lead people's minds and to promote the different social trends, which illustrate the development of contemporary music can not be confined within market range. Music should not only be to adapt to the public aesthetic level, but also to reflect the social context of the times to spread the correct values.

\section{References}

[1] Aaron Copland: Our New Music, New York, Whittlesey House, 1941, pp.229.

[2] (Germany) Theodor Adorno, trans, E.B.Asthon. Introduction to the sociology of music[M].America: Seabury Press, 1976.

[3] (Germany) Theodor Adorn, tran, E.B.Asthon. Introduction to the sociology of music[M]. America: Seabury Press, 1976, pp.247. 